\title{
The effect of Panchagavya formulations in the case of CA Rectum
}

\author{
Case Report
}

\section{Nandini Bhojraj', Gaurav Sawarkar²*}

\author{
1. Senior Consultant, Kamdhenu Go-Vigyan Anusandhan Kendra, Nagpur, Maharashtra, India. \\ 2. Associate Professor, Dept. of Rachana Sharir, Mahatma Gandhi Ayuved College, Hospital \& Research Centre, \\ Datta Meghe Institute of Medical Sciences (Deemed to be University), Wardha, Maharashtra, India.
}

\begin{abstract}
The faulty lifestyle, polluted environment, increasing use of pesticides, addictions leads to trigger the health issues; the cancer is one of them. Due to disease, one lac people are dying yearly; out of the $10 \%$ of the population diseased with colon and rectum cancer. In the present case study, the patient diagnosed with CA Rectum, operated at RST Regional Cancer Centre, Nagpur. APR with positive pelvic exenteration and later advised for Chemo-Radiation therapy. But, the patient herself denied for the chemoradiation and opted for preventive, therapeutic intervention at Go-Vigyan Anusandhan Kendra, Nagpur. Palliative treatment like Kamdhenu Gomutra Arka, Panchagavya Ghrit and Kamdhenu Haladi Ghanvatin was started in 2008. Simultaneously for a short duration, Bibhitakavleha, Panchtikta Ghrit, and Kushmandavaleh was prescribed. Treatment was continued for eight years except for the summer season, as the patient had mild rashes in the hot season. Before discontinuation of the therapy, CT scan chest and abdomen was done at RST Regional Cancer Centre, Nagpur, in August 2016. Not a single abnormality was observed in the scan. In the present case study, it was found that the cow products cumulatively have an effect of anti-oxidant, immunomodulation, and detoxification.
\end{abstract}

Key Words: Cancer, Gomutra, Panchagavya, Anti-oxidant.

\section{Introduction}

Cancer is the burning issue in today's era; many people threatened about its vulnerability. Up to 2017, near about 9.6 million people have died from the various forms of cancer (1). The problem is severed in higher-income countries. There is not a perfect remedy for the disease, only early detection is the way of survival. Chemo-radiation therapy has various side effects leading to severe fatigue, hair loss, skin changes, nausea, vomiting, gastric trouble, tenderness, shortness of breath, etc. (2). But world passing by Indian legacy concerning to Kamdhenu i.e., Indian cow. Indian cow product Panchagavya has various benefits practical on various human being problems. It acts as anti-oxidant, immunomodulatory, detoxifier, useful in psychosomatic disorders also (3). The present case study is the success story for using Indian cow Gomutra Ark and Panchagavya products in the case of CA Rectum.

\section{Patient Information}

Thirty-eight years of female patient complaining of pain in the anal region, irregular bowel habit with per rectal bleeding, and severe rectal pain.

\section{* Corresponding Author:}

\section{Gaurav Sawarkar}

Associate Professor, Dept. of Rachana Sharir, Mahatma Gandhi Ayuved College, Hospital \& Research Centre, Datta Meghe Institute of Medical

Sciences (Deemed to be University),

Wardha, Maharashtra, India

Email Id: drsawarkar.gaurav@,gmail.com
Treated by many general practitioners, but satisfactory relief was not seen in patient condition, and it was referred to a gastroenterologist after thorough investigation patient diagnosed with CA Rectum. For further treatment, the patient was approached to RST Regional Cancer Centre, Nagpur, and operated in 2007, APR with positive pelvic exenteration, and later advised for Chemo-Radiation therapy. The patient refused to Chemo-Radiation therapy and consulted on $8^{\text {th }}$ March 2008 to Go-Vigyan Anusandhan Kendra, Nagpur, for further treatment.

\section{Clinical Findings}

On examination, the general condition of the patient was poor, afebrile, conscious, but irritated. Blood pressure $100 / 60 \mathrm{~mm}$ of $\mathrm{Hg}$, severe pallor, weight $52 \mathrm{~kg}$. Bilateral fine crepitus and rhonchi present. Severe pain at right breast near axilla (visual analog scale $=10$ ). Previous complaints of patients like irregular bowel habits, per rectal bleeding, and severe rectal pain were lessened but not resolved entirely.

\section{Diagnostic Assessment}

Inflammatory granulation tissue and necrotic tissue feature s/o Adeno Carcinoma was observed in histopathology. On the USG abdomen, heterogeneous mass is seen in the pelvis. In X-ray chest, mediastinal widening plural, traced, lymph nodes were observed in operative notes surgeon recorded recto sigmoidal growth, adhesions to uterus and post vaginal wall, anterior pelvic exenteration with posterior pelvic exoneration. 


\section{Therapeutic Intervention}

Table: 1 Details of preventive palliative therapeutic intervention

\begin{tabular}{|c|c|c|c|c|c|}
\hline SN & Medicine & Dose & Frequency & After drink & Time specification \\
\hline $\mathbf{1}$ & Kamdhenu Gomutra Arka & $15 \mathrm{ml}$ & Twice a day & Warm water & Empty stomach \\
\hline $\mathbf{2}$ & Panchagavya Ghrit & $10 \mathrm{ml}$ & Twice a day & Dal water & With meal \\
\hline $\mathbf{3}$ & Kamdhenu Haladi Ghanvati & $500 \mathrm{mg}$ & Twice a day & Warm water & After meal \\
\hline $\mathbf{4}$ & Kushmandavleh & $5 \mathrm{gm}$ & Twice a day & Milk & After lunch for three months \\
\hline $\mathbf{5}$ & Bibhitakavleh & $5 \mathrm{gm}$ & Twice a day & Honey & For one month \\
\hline $\mathbf{6}$ & Panchtikta Ghrit & $5 \mathrm{gm}$ & Once a day & Warm water & Empty stomach at morning \\
\hline
\end{tabular}

\section{Follow-up and Outcomes}

Table: 2 Before, After and follow-up Haematological-Biochemical investigation

\begin{tabular}{|c|c|c|c|c|}
\hline $\mathbf{S N}$ & Investigations & Before treatment & After treatment & Follow-up \\
\hline & & March 2008 & August 2016 & December 2019 \\
\hline $\mathbf{1}$ & Haemoglobin & $9.5 \mathrm{gms} \%$ & $14.0 \mathrm{gms} \%$ & $13.9 \mathrm{gms} \%$ \\
\hline $\mathbf{2}$ & Total RBC & $3.80 \mathrm{million} / \mathrm{ul}$ & $4.50 \mathrm{million} / \mathrm{ul}$ & $5.30 \mathrm{million} / \mathrm{ul}$ \\
\hline $\mathbf{3}$ & Total Leucocytes & $10,500 \mathrm{cu} / \mathrm{mm}$ & $8,500 \mathrm{cu} / \mathrm{mm}$ & $6,100 \mathrm{cu} / \mathrm{mm}$ \\
\hline $\mathbf{4}$ & Platelet count & $1,40,000 \mathrm{cu} / \mathrm{mm}$ & $2,93,000 \mathrm{cu} / \mathrm{mm}$ & $3,80,000 \mathrm{cu} / \mathrm{mm}$ \\
\hline $\mathbf{5}$ & Blood urea & $20.00 \mathrm{mg} / \mathrm{dl}$ & $15.30 \mathrm{mg} / \mathrm{dl}$ & $18.37 \mathrm{mg} / \mathrm{dl}$ \\
\hline $\mathbf{6}$ & Sr. Creatinine & $0.97 \mathrm{mg} / \mathrm{dl}$ & $0.60 \mathrm{mg} / \mathrm{dl}$ & $0.66 \mathrm{mg} / \mathrm{dl}$ \\
\hline $\mathbf{7}$ & Sr. Sodium & $154.6 \mathrm{~mol} / \mathrm{L}$ & $141.6 \mathrm{~mol} / \mathrm{L}$ & $137.0 \mathrm{~mol} / \mathrm{L}$ \\
\hline $\mathbf{8}$ & Sr. Potassium & $5.01 \mathrm{~mol} / \mathrm{L}$ & $3.98 \mathrm{~mol} / \mathrm{L}$ & $4.10 \mathrm{~mol} / \mathrm{L}$ \\
\hline
\end{tabular}

Table: 3 Details of assessment of quality of life FACIT version-4

\begin{tabular}{|c|c|c|c|c|}
\hline SN & Quality of life domains & Before Treatment & After Treatment & $\begin{array}{c}\text { Follow-up } \\
\text { August 2016 }\end{array}$ \\
\hline $\mathbf{1}$ & March 2008 & 22 & 32 \\
\hline $\mathbf{2}$ & Emotional well-being & 2 & 25 & 37 \\
\hline $\mathbf{3}$ & Functional well-being & 4 & 25 & 38 \\
\hline $\mathbf{4}$ & Physical well-being & 1 & 17 & 31 \\
\hline
\end{tabular}

The patient continued this treatment for eight years, and before discontinuing the treatment, the patient had advised for CT Chest Abdomen at RST Regional Cancer Centre, Nagpur, in August 2016. In radiological investigations, it was observed that there were no lung lesions, no mediastinal nodes, no abnormality is seen in abdominal organs as well as no inflammatory changes found.

\section{Discussion}

The patient got relief and observed increased confidence in daily routine. It was an enormous response to preventive palliative therapeutic intervention. There was only one limitation to the case report that the patient belongs to Pitta dominance Prakruti and getting a mild rash on the skin in hot seasons, so for every summer season, treatment was discontinued for one month. Kamdhenu Gomutra Arka U.S. Patent (No. 6896907) is the distilled cow urine that possesses anti-cancer properties that protect DNA, repair it rapidly, and have immunomodulatory and anti-oxidant effect $(4,5)$. Panchagavya Ghrit is a medicated ghee manufactured with five cow products like cow ghee, cow milk, cow urine, cow dung juice and cow curd, reported anti-oxidant property having free radical effective in degenerative diseases, cancer, liver diseases, etc. It is well hepatoprotective $(6,7)$. Kamdhenu Haladi Ghanvati is playing a vital role in boosting immunity and giving shield from frequent illness. It is useful in detoxification of the body (8). The cumulative effect of all the medicine prescribed to the patient acts as an anti-oxidant, immunomodulatory, detoxifier, having proved anti-cancer activity $(3,9)$.

Avaleha is the secondary type of preparation useful for administration for various drugs having better absorption in digestive system (10). The Bibhitakavaleha- Bibhitaki (Terminalia bellirica Roxb.) is Kashaya Rasa, Madhura Vipaka, Ushna Veerya \& Laghu, Ruksha Guna is having the property of pacification of Kapha and Vata which helps to balance the Doshas. Mild laxative property of Bibhitaki facilitates Vataulomana and normalizes the direction of Vata (11). The Panchtikta Ghrita pacifying Vata reduces the sharp reflexes and nourishes the gastrointestinal tract (12). Kushmandavleh pacifies the Pitta Dosha, soothes the stomach linings, and controls the gastric secretion. It provides nourishment to the gastric lining, improves appetite, and increases the strength and reduces frailty (13).

\section{Conclusion}

It was concluded that the cow products are cumulatively having an effect of anti-oxidant, immunomodulation, detoxification. Bibhitakavleha, Panchtikta Ghrit, and Kushmandavaleh also nourishes and stabilized the imbalance Dosha. The abnormal finding in the scan normalized with the Ayurveda treatment. There is a necessity to conduct the clinical trial as an adjunct therapy in cancer cases to increase 
the living standard of the patient and minimize the side effects of radiation.

\section{Patient Perspective}

The patient is pleased and satisfied with the treatment. She is living her healthy life without any complication, hesitation, and stress.

\section{Informed Consent}

Informed consent of the patient was taken for the publication of the case report.

\section{Conflict of Interest}

No conflict of interest.

\section{Acknowledgment}

We are very grateful to Datta Meghe Institute of Medical Sciences (Deemed to be University), Wardha and Kamdhenu Go Vigyan Kendra, Devalapar to provide research assistance and financial support.

\section{References}

1. Roser M, Ritchie H. Cancer. Our World Data [Internet]. 2015 Jul 3 [cited 2020 Jul 12]; Available from: https://ourworldindata.org/cancer

2. Radiation Therapy Side Effects - National Cancer Institute [Internet]. 2018 [cited 2020 Jul 12]. Available from: https://www.cancer.gov/aboutcancer/treatment/types/radiation-therapy/sideeffects

3. Research work on Panchagavya [Internet]. [cited 2020 Jul 12]. Available from: http:// ayushportal.nic.in/panchagavya.html

4. Gosavi DD, Sachdev D, Salwe K. Immunomodulatory and anti-oxidant effect of gomutra ark in rats. 2011;16:6.
5. Joshi A, Chauhan RS. Anticancer effect of Taxus baccata and Indian cow urine distillate (CUD) on mice treated with Diethyl Nitrosamine Pathomorphological study. 2014;5(11):5.

6. Jirankalgikar NM, Nariya PB, Athavale AV, De S. Trividha Snehapaka of Panchagavya Ghrita: A critical comparative evaluation. J Ayurveda Integr Med. 2013;4(2):107-13.

7. Assessment of Nootropic Activity of Panchagavya Ghrita in Animal Models. 2015;5(8):5.

8. Go Vigyan Anusandhan Kendra [Internet]. Go Vigyan Anusandhan Kendra. [cited 2020 Jul 12]. Available from: http:/govigyan.com/pages/ research-patents-on-cow-products-go-vigyan

9. Patel P, Joshi C, Funde S, Palep H, Kothari V. Prophylactic potential of a Panchgavya formulation against certain pathogenic bacteria. F1000Research [Internet]. 2018 Oct 8 [cited 2020 Jul 12];7. Available from: https://www.ncbi.nlm.nih.gov/pmc/ articles/PMC6206607/

10. Rathi B, Wanjari A, Rajput D, Khan M, Rathi R. Pharmaceutical standardization of Chyawanprash prepared by two different methods. 2018;10.

11. Wajpeyi SM, Deshmukh M, Bhojraj N. Efficacy of Bibhitakavaleha in Management of Kaphaja Kasa with special reference to Chronic Bronchitis. Int J Ayurvedic Med. 2020 Jul 3;11(2):255-60.

12. Sawarkar P, Deshmukh M, Sawarkar G, Bhojraj N. A Comparative Efficacy Study of the Panchtikta Ghrita Matra Vasti and Panchtikta Ghrita Marsha Nasya in Cervical Spondylosis. Int J Ayurvedic Med. 2020 Jul 3;11(2):218-27.

13. Tadasad S, Katti BH, Sajjanshetti MR, Kannolli GN. Clinical evaluation of the effect of Khanda Kushmanda avalehya in raktapradara (Abnormal Uterine Bleeding). J Ayurveda Integr Med Sci ISSN 2456-3110. 2018 Sep 19;3(5):36-44. 